\title{
The Czechs: Jobs and Work
}

\author{
PETR MAREŠ ${ }^{\star \star}$ \\ School of Social Studies, Masaryk University, Brno
}

\begin{abstract}
The Czech population attaches great importance to work in their lives, both as a source of income and as a sphere in which to realise their human potential. A factor analysis of work aspects identified three general factors in the aspects of work: an 'instrumental and trade-off' factor (good pay and good job security; generous holidays, good working hours and not too much pressure; pleasant people to work with and good working conditions); a 'social' factor (an interesting job, a useful job, a responsible job, a respected job and meeting interesting people); and a 'self-fulfilment' factor (chances for promotion, possibility of achievement, opportunities to use initiative, opportunity to use one's abilities). The importance attached to individual work aspects differs among members of individual social classes, as well as between men and women within these classes.
\end{abstract}

Czech Sociological Review, 2001, Vol. 9 (No. 1: 69-84)

\section{Introduction}

Work has always seemed to be a fundamental human need, an indispensable social bond, a virtue, and the main source of self-esteem. However, Gorz [1999: 55] is right in saying that work that gave one membership of a given society (termed as 'wage-based' or 'salary-based') is clearly not work in the anthropological or philosophical sense. As a product of a given civilisation, today, it is paid work - a job. Giddens [1994: 176] says: "Most pre-modern societies seem to have no word for 'work', presumably because working wasn't readily distinguishable from other activities". According to Beck, the importance that work has acquired in industrial society has no parallels in history. "Wage labour and an occupation have become the axis of living in the industrial age" [Beck 1992: 139]. An army of workers totalling more than 380 million people live in the countries of Europe, including Russia [Gesano 1999].

Now, both the economic well-being and consumption habits of a family symbolise the success of one's own work. Men's success is essentially connected with their economic and professional achievements. Six key characteristics of paid work are relevant here. Money, activity level, variety, temporal structure, social contacts, and personal identity [Giddens 1989: 505]. ${ }^{1}$ Work also guarantees a fundamental social experience. It may be perceived as an instrument for gathering resources needed for a 'true life' beyond work (time after working hours on weekdays, weekends and holidays, as well as retire-

*) This study was written with the support of the Grant Agency of the Czech Republic (grant no 403/99/0326 "European Values Study - Česká republika 1999").

**) Direct all correspondence to Doc. PhDr. Petr Mareš, CSc., Department of Sociology, School of Social Studies of Masaryk University, Gorkého 7, 60200 Brno, e-mail pmares@fss.muni.cz

1) Similarly, Jahoda suggests that work serves five psychological functions: First, it imposes a time structure on the day; second, it implies shared experience and regular contacts with people outside the family; third, it links an individual to goals which transcend his or her own; fourth, it defines aspects of personal status and identity; fifth, it enforces activity [Jahoda 1979b]. 
ment). A 'job' is an instrument for sustaining life and the individualisation of life styles. On the other hand, 'work' in the sense of 'working activity' may represent a value in itself. Above all, it is an instrument for the expression of human creative potential.

Paid work is important also from the perspective of society's progress towards democracy. Most human rights are linked to work. "Jobs as a key to life chances in the work societies were for a long time not merely the entry ticket to the world of provisions but also for entitlements to citizenship" [Dahrendorf 1989: 148]. Also, Beck states that "Democracy arose in Europe and America as a democracy of work in the sense that political freedom relied on participation in paid work" [Beck 1998: 11].

In early modernity, paid work became a powerful instrument of the emancipation of the poor.

"The problem has been replaced by that of the labourers who ought to be treated, like all other groups, as rational subjects of exchange. They are not a special aspect of the wise administration of the state but individuals who, like all other property owners, pursue their self interest and seek to better their conditions, and those of their families, by the only means at their disposal and their only property: their labour" [Dean 1991: 135].

On the other hand, many authors (Adam Smith, Karl Marx, Durkheim, Weber among others) have described the process of a detailed division and standardisation of labour which led to its disintegration into simple working operations. Some authors perceived this process as a source of work effectiveness (Frederick Winslow Taylor, Max Weber); others later turned their attention to limits, both in achieving organisational goals and in terms of workers' satisfaction (Elton Mayo and Georges Friedmann). Fragmentary working tasks in industry often take less then a minute to perform, do not require any skill (deftness has replaced skill) and are monotonous and hard to carry out. Blue-collar workers in particular (but increasingly more often also white-collar workers) feel they have little control over their working conditions and are denied the opportunity to influence decisions about their jobs. As it only takes a few days to train a person in a single work operation, workers have become interchangeable and thus also expendable. ${ }^{2}$

In actual fact, work is usually not very attractive, gratifying, satisfying, or integrating. Divided work no longer pays off and is no longer rewarding for those who perform it [Friedmann 1970]. ${ }^{3}$ The human inner need for participation in active work has gradually been recognised as well. It is becoming increasingly more evident that people's attitudes to work and their social contacts with the other people in the workplace are reflected in their work performance.

Things are made even more complicated by the fact that "high unemployment in the midst of economic growth raises questions about economic development, the history of work, and citizenship" (see above) (...) "Modern societies are work societies, built

\footnotetext{
2) Neo-Marxists [Braverman 1974], among others, have described what implications this has for the standing of workers in the labour market and what room it leaves for 'working under constraint'.

3) As a reaction to the above-mentioned situation, ideas such as corporate cultures concept, emphasis on human relations, management under conditions of chaos - Peters [1987], flexibility Toffler's conception of adhocracy [Toffler 1985], and a reaction to the Japanese challenge Ouchi's 'z-theory' [1981]) aiming at the activation of workers' creative potential, skills and knowledge. 
around the work ethic and occupational roles, but they also seem to be driven by the vision and apparently increasingly realistic perspective of a world without work" [Dahrendorf 1990: 141-143]. However, opportunities for paid work are becoming increasingly scarcer. Bělohradský [1999] maintains that it is the deepest source of the disconcertion of post-industrial democracy that it fails to attach human meaning to a tendency which most typifies it as post-industrial - that is to 'job scarcity'. "In fact, from being a burden, work has become a privilege" [Dahrendorf 1990: 144].

The idea of moving beyond a wage-based society, where working time will cease to be the dominant social time, is discussed increasingly more often. Beck [Pongs 1999: 54] maintains that most people will lose their jobs in the future (capitalism without work has begun to emerge). He suggests separating material security from the monopoly of paid work and turning attention to diverse alternative activities. What is the solution to this situation? One of the considered options is a somewhat vaguely formulated idea of a leisure-time society. ${ }^{4}$ According to certain authors, the ideology of work has begun to erode. People will recognise that the right to work and the right not to work are of equal importance. Nonetheless, most definitions of leisure time define it in relation to work (each of them losing significance in the absence of the other). Jahoda [1979a] arrived at a similar conclusion and suggested that being unemployed is different from having leisure time. The concept of 'civil labour' [Beck 2000] represents another possible alternative to paid work. However, a number of authors - for example Clauss Offe - are rather sceptical about this [Pongs 1999: 54].

In spite of both the contemporary evidence for alienation in the modern employment system (see critiques by Marx, Marcuse, Braverman and others) and assertions about a decline in job opportunities and the death of the work ethic (Dahrendorf, Bell, Beck, Bělohradský and others), most people continue to desire to hold a job [Marx 1978, Marcuse 1964, Braverman 1974, Dahrendorf 1990, Bell 1974, Beck 1998, Bělohradský 1999]. Moreover, they are forced to do so. Employment and jobs remain the determinants of their personal, family and social lives. People fear losing their jobs, and work conditions (economic, social and psychological) represent a means of evaluation. Individuals tend to be more or less satisfied with these conditions. Supposedly, the level of satisfaction varies according to individual personal characteristics, as well as in dependence on sex, age, membership of a social class, etc.

Utilising data from the European Values Study, this article aims at answering the following questions: Do the Czech people experience any form of job security? How satisfied are they with their job/work? What role does their job/work play in their lives and what is its relationship to the family, friends and leisure time? What aspects of work do they consider important and what general dimensions do these aspects form? To what extent are individual social classes in Czech society distinguishable with regard to the importance that they attach to various work aspects? Which general dimensions, based on these work aspects, are more representative of one class than of another? In what way does the situation in the Czech Republic differ from that in other European countries? Does it show similarities with the situation in other post-communist countries?

4 ) Indications of such visions can be found in the social utopia of the 17th-19th centuries and with even more force in the 1930s [e.g. Keynes 1931] and the 1960s [e.g. Fourastié 1965]. Nonetheless, they did not acquire a more real form until related to the technological and social changes of the 1990s. 
This article, as well as other ones in this issue, is based on the findings of the European Values Study from 1999 (a previous research wave was conducted, among other countries in the Czech Republic also, in 1991). The study consisted of an extensive questionnaire survey. In the Czech Republic, data collection was carried out by teams headed by Řehák and Rabušic under the support of the Grant Agency of the Czech Republic (grant No 403/99/0326 “European Values Study - Czech republic 1999"). Among the advantages, there ranks the possibility to compare the Czech Republic with other European countries. Disadvantages are twofold. First, the data is somewhat limited. It comes not from a special questionnaire but only from several scales included in a questionnaire of an omnibus type. Second, the author participated neither in the operationalisation of the original concepts, nor in the preparation of the questionnaire. He is only interpreting the data that is available.

\section{The Importance of a Job and Work}

The value of work is relatively high in the Czech Republic [European... 1999]. After all, this is also the case in other European countries. ${ }^{\mathbf{5}}$ In most of them, if not in all, work is considered an important or even very important component of human life. However, certain indicators suggest that individual countries' populations may be motivated differently in this respect. The majority of Czech respondents $(96.8 \%)$ consider work important (53.0\% even very important). These findings are analogous to those obtained in 1991 (93.6\% and 59.7\%, respectively). Most respondents (84.8\% in 1999 and $87.6 \%$ in 1991) regard the possible decrease in the importance of work in the near future to be a negative trend. Members of all social classes, as well as both men and women, identify with this opinion. No differences in the evaluation of this trend were found among members of different age groups either.

Table 1. Importance of work, family and leisure in one's life - Czech Republic, 1999 (valid \%)

"Please say, for each of the following, how important it is in your life."

\begin{tabular}{lccccc} 
& & very & quite & not & not at all \\
& important & important & important & important \\
\hline work & count & 1007 & 771 & 100 & 21 \\
& $\%$ & 53.0 & 40.6 & 5.2 & 1.1 \\
family & count & 1611 & 259 & 28 & 3 \\
& $\%$ & 84.8 & 13.6 & 1.5 & 0.2 \\
leisure time & count & 397 & 1100 & 366 & 31 \\
& $\%$ & 21.0 & 58.1 & 19.3 & 1.6 \\
\hline
\end{tabular}

Source: [European... 1999].

Although no significant differences were identified in the perception of the importance of work by individual social categories, male manual workers do value work somewhat less

\footnotetext{
5) Among the countries where people attach greater importance to work (higher proportion of respondents who evaluate it as 'very important' in their life) are, for example, Sweden (89.7\%) and Poland (78.1\%). Among the countries where people attach lower importance to work (low proportion of answers 'very important') are Denmark (39.5\%) and the Netherlands (47.4\%). The situation in the Czech Republic (53.0\%) is comparable with that in Ireland (51.1\%), Germany (50.3\%), Lithuania (54.2\%), and Estonia (51.4\%) [European... 1999].
} 
than the others. ${ }^{6}$ Also, the importance of work in one's life increases with age (41\% of respondents in the 17-29 age group consider work important for their life, while in the 5051 age group it is $60 \%$ ). The correlation matrix of the importance of 'work', 'family', 'leisure time' and 'friends' in one's life revealed a medium correlation between work and family on the one hand (Spearman's $\rho=0.220$; the correlation of both variables with the other items is significantly lower), and between leisure and friends on the other hand (Spearman's $\rho=0.285$; the correlation of both variables with the other items is significantly lower). ${ }^{7}$ Partial correlation coefficients controlled for sex and class suggest that both the variables slightly intervene with these findings. The link between the choice of work and family is stronger for men than for women (as well as for the lower class in comparison with upper-middle and upper classes). Overall, all the four above-mentioned items correlate more closely with one another with regard to their importance in life than does any one of them with the remaining two items, i.e. politics and religion. The results of a multidimensional scaling of all these items come unambiguously to the same conclusion.

Table 2. Reasons for taking a job - Czech Republic 1999 (valid \%)

"Do you agree or disagree with the following statements?"

\begin{tabular}{lcrc} 
& agree & neither/nor disagree \\
\hline You need to have a job to fully develop your talents & 79.5 & 12.0 & 8.5 \\
It is humiliating to receive money without having & & & \\
$\quad$ to work for it & 46.8 & 23.4 & 29.8 \\
People who don't work turn lazy & 79.0 & 9.8 & 11.2 \\
$\quad$ Work is a duty towards society & 63.0 & 19.5 & 17.5 \\
People should not have to work if they don't want to & 31.7 & 17.4 & 50.8 \\
$\quad$ Work should always come first, even if it means & & & \\
$\quad$ less spare time & 55.7 & 22.3 & 22.0 \\
\hline
\end{tabular}

Source: [European... 1999].

Correspondence analysis of these items shows that the conviction 'work is a duty towards society' functions as a creed of the middle class (both of men and women - particularly in contrast to lower-class men, where only $49 \%$ of respondents agree with the statement), as does the statement 'you need to have a job to fully develop your talents'. The opinion that 'it is humiliating to receive money without having to work for it' is typical more for lower-class women ( $63 \%$, while only $33 \%$ of lower-class men share this opinion) who also tend to agree less than other respondents with the statement that 'People should not have to work if they don't want to' (only 21\%). Upper-class and upper-middle-class men share with lower class men a strong belief that 'Work should always come first, even if it means less spare time'. Put differently: Lower-class men tend to agree less with the opinions that 'it is humiliating to receive money without having to work for it', 'work is a duty towards society', and 'people who don't work turn lazy'. On the contrary, they are more likely to agree with the statement that 'people should not have to work if they don't want to'. Holding these opinions, they differ not only from the other classes, but also from

6) As we shall see later in the text, they perceive work rather instrumentally. They aim above all at a satisfactory wage and job security (and fear unemployment more than other population groups).

${ }^{7}$ ) In the case of both pairs of items, the correlation is significant at the 0.005 level (2-tailed). 
women of the same class. These women appear to represent the opposite pole of the opinion spectrum. They tend to share with the middle classes the perception of work as duty and life without work as humiliating. What motivates middle-class members to work is thus above all a sense of social duty and the opportunity to make the most of their abilities (this is also stressed by middle-class women). Lower-class women tend to accentuate the humiliating character of unearned income. Upper-middle-class men associate their work motivation with a rather vague 'work comes first'.

\section{Do People Fear Losing Their Jobs? ${ }^{8}$}

Satisfaction with job security is quite high in Czech society: $57.3 \%$ of respondents evaluate it as satisfactory (values 6-10 on a ten-point scale), $36.9 \%$ as very satisfactory (values $8-10$ ) and $11.8 \%$ as absolutely satisfactory (value 10 ). Older people tend to express greater satisfaction with job security than younger people (values 8-10: $41 \%$ of respondents in the 50-59 age group, while a mere $27 \%$ of respondents in the 17-29 age group), as do upper-class and upper-middle-class members (values 8-10: 60\%) ${ }^{9}$ compared with the rest (values 8-10: middle-class, white-collar workers 40\%, skilled and semi-skilled workers $27 \%$, unqualified labourers $19 \%$ ).

Data from public opinion polls conducted by the Institute for Public Opinion Polls (IVVM) makes it possible to reconstruct the trend in the public reflection of the labour market after 1989. In April $2000,{ }^{10}$ only $12 \%$ of respondents were convinced that their employers were facing difficulties and an uncertain future (between 1992 and 2000, their proportion fluctuated between $10 \%$ and $20 \%$, only in 1992 and 1993 did it increase to $27 \%$ ). A mere $1 \%$ of respondents thought that the company where they were employed would close down (their proportion was about 1\% or 2\% between 1992 and 2000, in 1992 and 1993 it again increased to 5\%). The proportion of respondents who believed that they were at risk from redundancy was not high either (12\%) and has not changed much between 1992 and 2000. Job insecurity is more frequently found in larger enterprises than in smaller ones, and in private companies than in state-owned ones. Nonetheless, the majority of respondents expect further growth in unemployment in the Czech Republic $(33 \%$ anticipate a sharp increase and $40 \%$ moderate growth). ${ }^{11}$ At the same time, $31 \%$ of respondents are convinced that people remain unemployed because they 'are unable to find any work at all', $49 \%$ of them think that it is rather because these people 'are unable to find an adequate job' and only $14 \%$ maintain that 'the unemployed simply do not want to work'. ${ }^{12}$ To complete the picture, it should be added that the average rate of unemployment in the Czech Republic was about $9 \%$ in 2000, with the most seriously affected re-

8) Data for this section were drawn from research carried out by the Institute for Public Opinion Polls (IVVM).

9) It corresponds with stronger job security certitude among people with a graduate degree (values 8-10: $52 \%$ ) in comparison with elementary-educated people (values 8-10: $26 \%$ ).

${ }^{10}$ ) Institute for Public Opinion Polls (IVVM) at the Czech Statistical Office - April 2000 (representative sample of 1018 respondents, sampling error $\pm 3 \%$ ).

${ }^{11}$ ) Institute for Public Opinion Polls (IVVM) at the Czech Statistical Office - February 2000 (representative sample of 1045 respondents, sampling error $\pm 3 \%$ ).

12) $40 \%$ of respondents demanded that the unemployed were obliged to accept any job (values 1-3 of a ten-point scale) and $20 \%$ of respondents conceded them the right to refuse an inadequate job (values $8-10$ of the scale). 
gions (the coal-mining areas of northern Bohemia) suffering from $15 \%$ unemployment. However, there are certain micro-regions in the country where unemployment amounts to as much as $35 \%$, and even exceeds $50 \%$ in extreme cases. Respondents' opinions on prioritising Czechs (over foreigners) and men (over women) when it comes to employment, and changes in these opinions since 1991, are not without interest either.

Table 3. Who should be given priority in getting a job - Czech Republic (valid \%)

"When jobs are scarce, employers should give priority to Czech people over immigrants" and "When jobs are scarce, men have more right to a job than women"

\begin{tabular}{lrrrr} 
& & agree & neither/nor & disagree \\
\hline give priority to Czechs & 1991 & 84.6 & 3.6 & 11.8 \\
& 1999 & 84.0 & 7.1 & 8.9 \\
& difference & -0.6 & +3.5 & -2.9 \\
give priority to men & 1991 & 49.8 & 8.3 & 42.0 \\
& 1999 & 18.4 & 15.8 & 65.9 \\
& difference & -31.4 & +7.5 & +23.9 \\
\hline
\end{tabular}

Source: [European... 1991, 1999].

\section{Work Satisfaction and the Meaning of Particular Aspects of Work}

Work satisfaction (measured on a ten-point scale) is relatively high in the Czech Republic: $79.1 \%$ of respondents identified with the positive half of the scale (values $6-10$ ), $54.8 \%$ placed themselves in the significantly positive part (values $8-10$ ) and $15.8 \%$ chose the extreme scale position (value 10). These findings fully correspond with data gathered in 1991 using the same measurement scale. Older people tend to be more satisfied with their job than younger people (values 8-10: 60\% of respondents in the 50-59 age group and $46 \%$ of respondents in the 17-29 age group), as do the upper-class and upper-middleclass members compared with the working class (values $8-10: 69 \%$ and $49 \%$, respectively).

Table 4. Job satisfaction - the Czech Republic (valid \%)

"Overall, how satisfied or dissatisfied are you with your job?"

\begin{tabular}{|c|c|c|c|c|c|c|c|c|c|c|c|}
\hline & & dissa & tisfied & & & & & & & satis & sfied \\
\hline & & 1 & 2 & 3 & 4 & 5 & 6 & 7 & 8 & 9 & 10 \\
\hline legenda & 1991 & 2.2 & 1.2 & 3.6 & 3.8 & 12.7 & 9.9 & 14.8 & 21.7 & 13.8 & 16.3 \\
\hline ten-point scale & 1999 & 1.7 & 0.6 & 3.9 & 4.2 & 10.5 & 9.8 & 14.5 & 24.0 & 15.0 & 15.8 \\
\hline & difference & -0.5 & $-0.6+$ & $+0.3+$ & +0.4 & -2.2 & -0.1 & -0.3 & +2.3 & +1.2 & -0.5 \\
\hline legenda & 1991 & & 7.0 & & & & 1.2 & & & 51.8 & \\
\hline three-point scale ${ }^{*}$ & 1999 & & 6.2 & & & & 9.0 & & & 54.8 & \\
\hline & difference & & -0.8 & & & & 2.2 & & & +3.0 & \\
\hline
\end{tabular}

$\left.{ }^{*}\right)$ This scale combines points 1, 2, 3 and points 4, 5, 6, 7 and points $8,9,10$.

Source: [European... 1991, 1999].

A quarter of a century ago, Možný [1974] attempted to operationalise work in the Czech Republic in terms of its intuitively identified attributes. He correlated respondents' satis- 
faction with individual work aspects. ${ }^{13}$ The conducted linkage analysis [McQuitty 1964] in a correlation matrix resulted in dividing the work process into three general dimensions (the number of items was reduced in a similar way as when using factor analysis). Respondents evaluated their job according to:

1. the opportunity for personal fulfilment the work provides (interesting work, chances for promotion, opportunity to use one's abilities, wage and the closely related exertion required of the job). ${ }^{14}$

2. working conditions and environment (working environment, organisation of work, and a company's social policy)..$^{15}$

3. the social contacts which it imposes on people (colleagues and superiors).

The data collected by Možný twenty-five years ago deserves comparison with the current data. Our file does not include data on satisfaction with work aspects, but data on the importance which respondents attach to these aspects (the perspective has changed). Thus it is impossible to comment on the shift in content and try to compare the situation in preand post-communist Czech society. However, what does result, interestingly enough, from the comparison of both researches is that in both cases, analogical social groups are formed whose attitudes vary (with respect to the favoured aspects of work in 1999, and with respect to work aspects with which they are satisfied in 1974). As expected, the factors include sex, age and education (class membership was not monitored in 1974).

In the case of EVS data from 1999 we used a factor analysis. Only then did we present our findings on the importance attached to individual job aspects by the respondents knowing which factor individual aspects belong to (table 5). A factor analysis ${ }^{16}$ of the evaluation of the importance of work aspects identified three factors.

\footnotetext{
13) Respondents' satisfaction was measured on a set of Likert scales (one scale for each of the aspects). Contrary to the current focus on the importance of individual work aspects for an individual, the practice of real socialism was concerned with actual satisfaction with these aspects. This concern was motivated by the aspiration of enterprises at that time aspiration to stabilise their personnel (the 'hit' in those years was research into the causes of fluctuation which used to be perceived as a negative phenomenon).

${ }^{14}$ ) The link between wages and the required exertion corresponds with the remuneration philosophy at that time. Rather than with job complexity and necessary qualifications, wage level used to increase with the required physical exertion.

15) The research was conducted in the real socialism era of the 1970s, when enterprises used to assume a number of social-policy functions typical of the welfare state.

16) Individual scales have the form of dummy variables. Factor analysis (Varimax rotation) seems to represent a relevant model for our data: Kaiser-Meyer-Olkin Measure of Sampling Adequacy $=$ 0.862 . The three identified factors exhaust $40 \%$ of the variance (each of them about $13 \%$ ), Bartlett's Test of Sphericity: Sig. 0.000. Appropriate factor loadings are mentioned in brackets following individual items (table 5).
} 
Table 5. Importance of certain aspects of work - Czech Republic (valid \%) "Here are some aspects of a job that people say are important. Please look at them and tell me which ones you personally think are important in a job."

\begin{tabular}{|c|c|c|c|}
\hline \multirow[b]{2}{*}{ Aspects of work } & \multicolumn{3}{|c|}{ mentioned } \\
\hline & 1991 & 1999 & difference \\
\hline \multicolumn{4}{|l|}{ Social aspects of work } \\
\hline a useful job for society (.615) & 51.8 & 32.4 & -19.4 \\
\hline a respected job (.603) & 44.5 & 35.2 & -9.3 \\
\hline opportunity to meet people $(.575)$ & 44.0 & 34.0 & -10.0 \\
\hline interesting job $(.508)$ & 64.6 & 56.7 & -7.9 \\
\hline a responsible job $(.455)$ & 40.9 & 29.0 & -11.9 \\
\hline good working environment (.508) & - & 57.7 & - \\
\hline pleasant colleagues $(.424)^{*}$ & 68.3 & 63.9 & +0.6 \\
\hline \multicolumn{4}{|l|}{ Material aspects of work } \\
\hline good pay $(.557)$ & 70.5 & 73.9 & +3.4 \\
\hline good job security $(.510)$ & 54.6 & 52.2 & -2.4 \\
\hline good working hours (.685) & 38.8 & 31.0 & -7.8 \\
\hline generous holidays (.667) & 19.0 & 16.9 & -2.1 \\
\hline not too much pressure (.459) & 36.2 & 35.6 & -0.6 \\
\hline \multicolumn{4}{|l|}{ Self-fulfilling aspects } \\
\hline opportunity for achievement (.734) & 48.1 & 38.1 & -10.0 \\
\hline chances for promotion $(.630)$ & 25.3 & 24.3 & -1.0 \\
\hline opportunity to use initiative (.661) & 37.8 & 29.7 & -8.1 \\
\hline opportunity to use one's abilities (.596) & 67.9 & 56.1 & -11.8 \\
\hline
\end{tabular}

*) but .327 with regards to the second factor.

Source: [European... 1999].

It is evident that most respondents accentuate 'an interesting job', 'pleasant people to work with' and 'an opportunity to use one's abilities'. As well as this, they emphasise 'good pay' and 'good job security'. Contrary to earlier findings (research conducted in 1991), the importance of aspects related to work's social dimension and to personal selffulfilment has declined. Conversely, material aspects of work have increased in importance (a job as a source of income and life security, working conditions). This development is due particularly to attitude changes among lower-class and lower-middle-class members. 
Scheme 1. Links between individual attributes of work - the Czech Republic, 1999 (figures above the links represent relevant Pearson coefficient values)

"Here are some aspects of a job that people say are important. Please look at them and tell me which ones you personally think are important in a job."
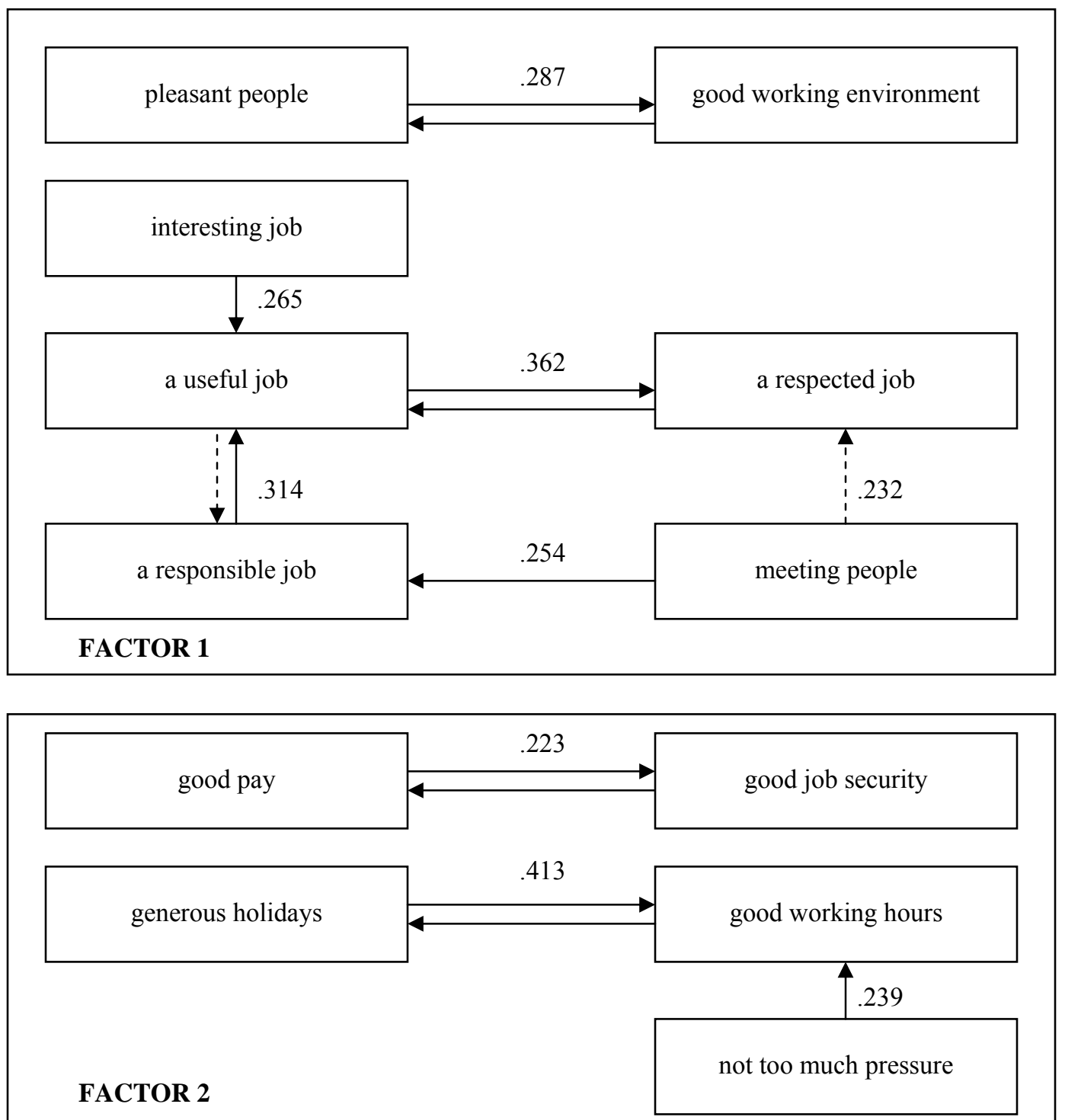


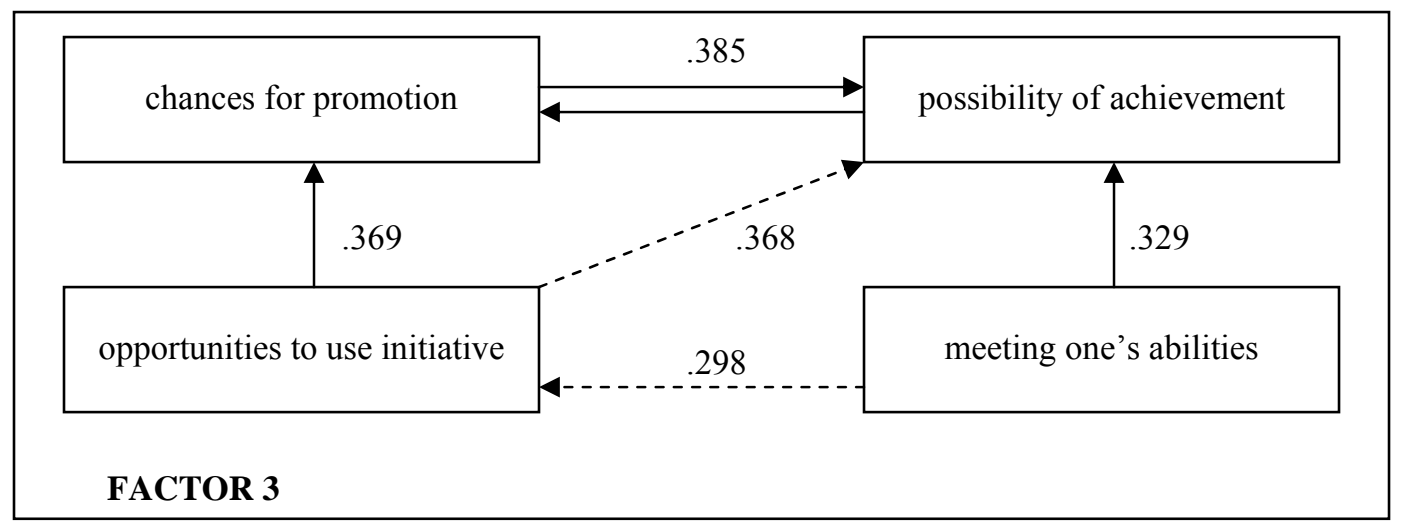

Source: [European... 1999].

Linkage analysis in a correlation matrix (scheme 1) provides us with more detailed information about the links between individual factors. Nevertheless, these aggregate results are hardly more than illustrative since the importance attributed to individual work aspects depends on gender, social class and age. For instance, as far as age is concerned, respondents under the age of 29 are relatively more likely than older people to attach importance to 'good pay' ( $84.1 \%$ compared to $77.2 \%$ of respondents in the $40-49$ age group and $70.6 \%$ of respondents in the $50-59$ age group), 'possibilities of achievement' (51.5\% compared to $35.6 \%$ of respondents in the $40-49$ age group and $26.3 \%$ in the $50-59$ age group), 'an interesting job' (66.1\% compared to $58.0 \%$ in the $40-49$ age group and $54.3 \%$ in the 50-59 age group), and 'an opportunity to use one's abilities' $(62.1 \%$ compared to $57.8 \%$ in the $40-49$ age group and $49.7 \%$ in the $50-59$ age group). The effect of gender and social class is shown in the following scheme of the correspondence analysis results (see scheme 2). Both women and men from the upper and upper-middle class value the same aspects of their jobs (women are more likely to appreciate 'using one's abilities', 'opportunity to use initiative', 'chances for promotion', 'a responsible job', 'possibility of achievement', while men are more likely to value 'an interesting job', 'a respected job', 'a useful job' and 'meeting people'). Their choices differ from those expressed by women and men from the lower classes ('good working conditions', 'not too much pressure', 'generous holidays', 'good pay', 'good working hours'). Women and men from the lower-middle classes and middle classes make their own specific choices as well, with the difference between men and women being greater than in both the previous cases (women tend to appreciate 'a respected job', 'a useful job', 'pleasant people', possibly also 'an interesting job' and 'meeting people'; men value 'possibility of achievement', 'a responsible job', 'opportunity to use initiative', and 'chances for promotion' in this respect, their preferences resemble those of higher-class-members - but also 'good pay', 'generous holidays', and 'not too much pressure' - and in this respect their preferences resemble those typical for the lower classes). 
Scheme 2. Importance of certain aspects of work: Effect of gender and class Czech Republic 1999

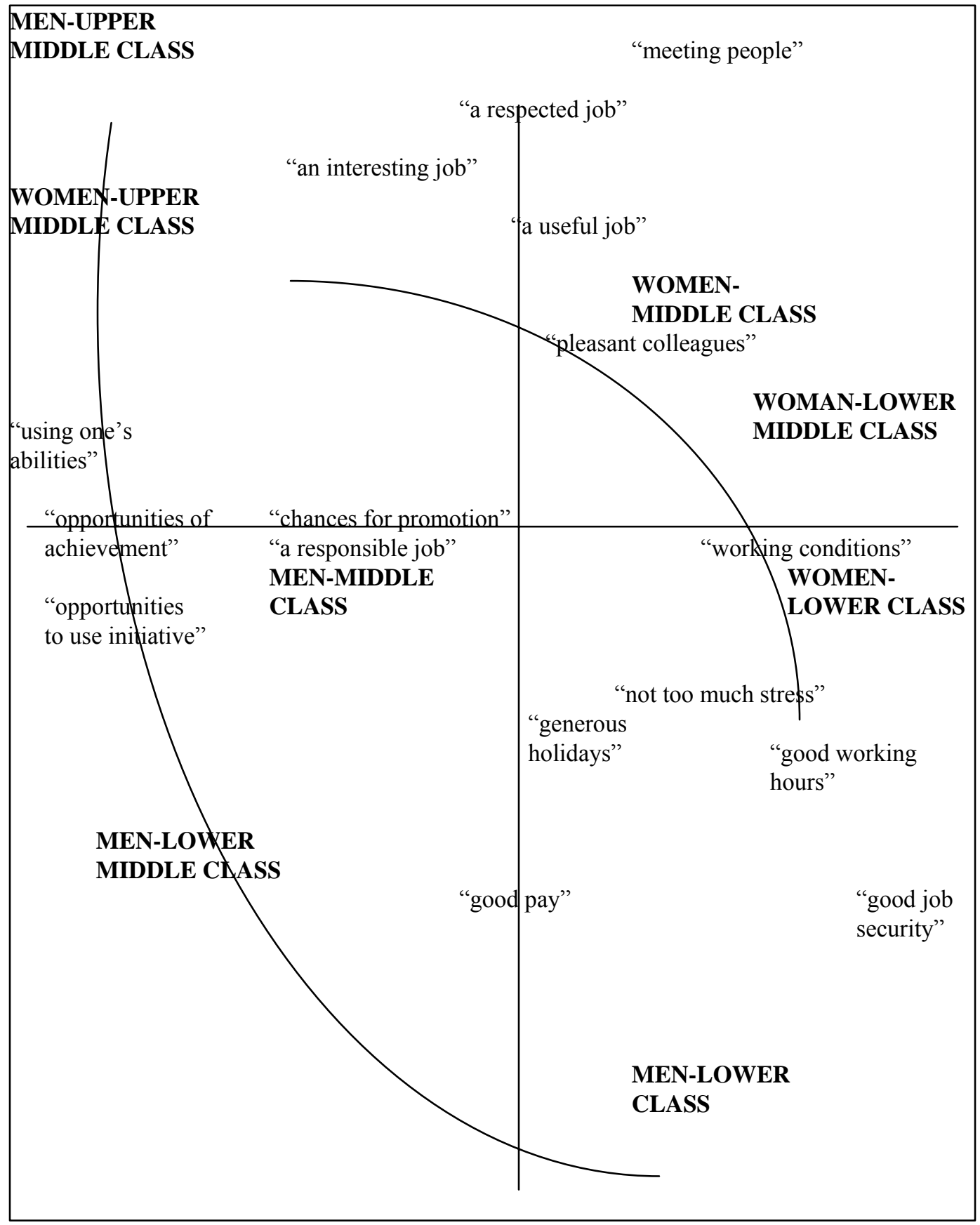

Source: [European... 1999].

Note: $\quad$ Correspondence data analysis was carried out with the use of the software LINDA (comparative factor analysis of profiles) designed by Jan Řehák (Institute for Sociology of the Academy of Sciences of the Czech Republic). 
The scheme makes it possible to determine in what way members of individual social classes differ in terms of the importance attached to various work aspects. The scheme also makes it clear that men and women within these classes differ in this respect as well - with the exception of the upper-middle class. A similar analysis can be carried out for individual European countries for which analogous data is available (the results of the correspondence analysis are shown in the following scheme).

Scheme 3. Importance of certain aspects of work - Europe 1999

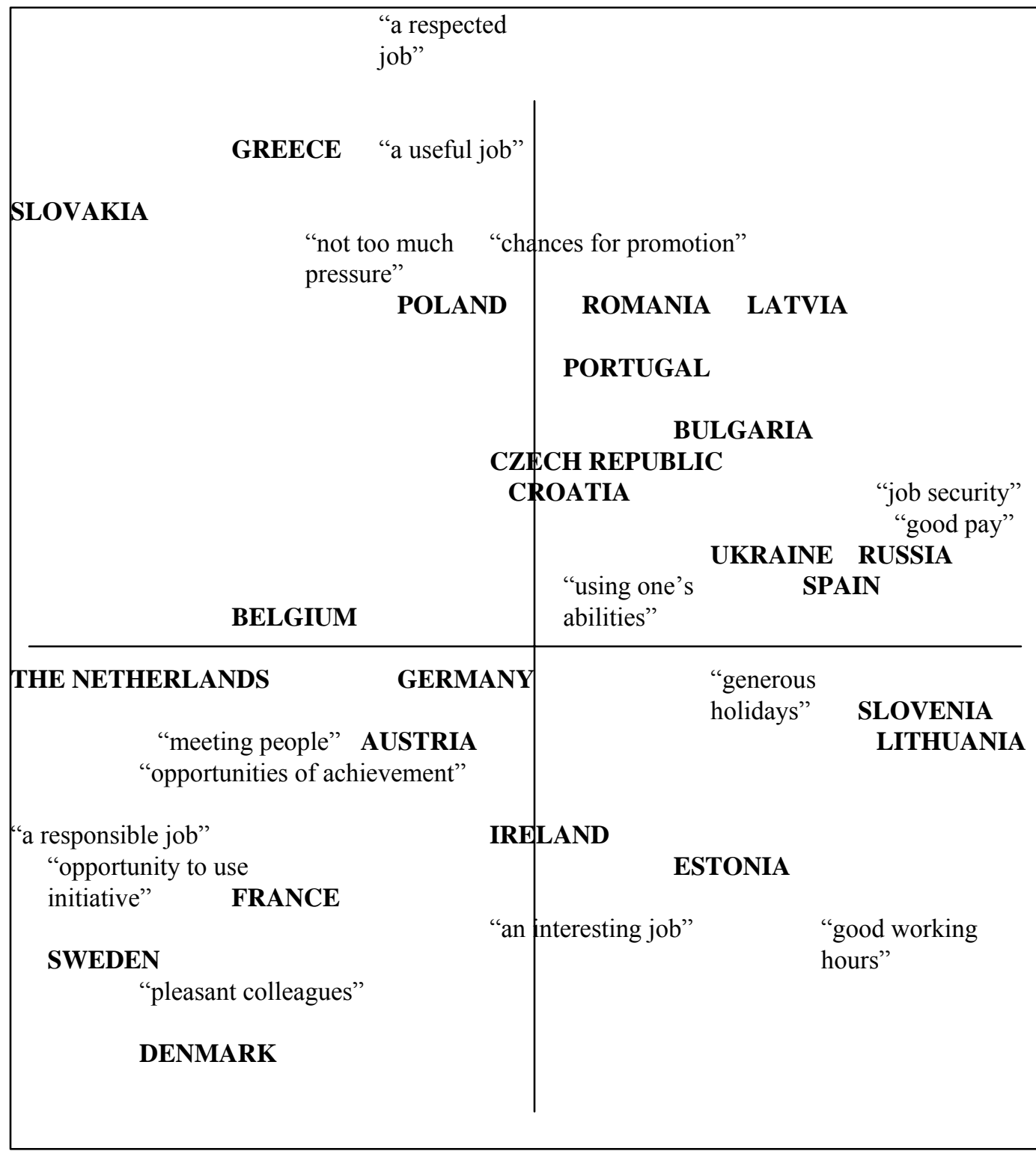

Source: [European... 1999].

Note: $\quad$ Correspondence data analysis was carried out with the use of the software LINDA [comparative factor analysis of profiles) designed by Jan Řehák [Institute for Sociology of the Academy of Sciences of the Czech Republic). 
This scheme is somewhat complicated to interpret. However, it allows for the conclusion that in the post-communist countries greater emphasis is placed on material aspects, such as 'good working hours' and 'generous holidays', as well as on 'job security' and 'good pay'. This applies more to Slovenia, Lithuania, Estonia, Latvia, Ukraine, Russia, and Bulgaria (as well as to Spain and Portugal) than to the Czech Republic and Croatia (and it does not apply to Poland and Slovakia). The EU countries attach greater importance to self-fulfilling aspects, such as 'a responsible job', 'opportunity to use initiative', and 'possibility of achievement' on the one hand, and to 'pleasant people to work with' and 'meeting people' on the other hand (Denmark and Sweden; France and Ireland also value 'an interesting job' and 'good working hours').

\section{Conclusions}

All over Europe, work is the most important source of income in modern society. This, however, does not exhaust its social role and its role in the lives of individuals. Contrary to the simplified view that work is primarily a source of income and (according to the principle of meritocracy) thus also of social status and social inequalities, a rather different view has been emerging since the 1930s. This view highlights those aspects of work that reinforce self-fulfilment, self-respect and social bonds. Work is perceived as a way of being autonomous and creative, an instrument that enables individuals to express themselves, establish contacts with other people, and develop their skills. The orientation toward self-fulfilment stands against the instrumental orientation. ${ }^{17}$ Besides, it is impossible to overlook the fact that work does not only determine one's nature of life (social status, life style and life chances), but also their standing in relation to the welfare state [Adriaamsens 1994]. All of this applies to Czech society, too, except for the fact that there is a third factor, 'social orientation', situated between the two mentioned above.

A factor analysis of work aspects identified three general factors formed on the basis of the differing importance attached to individual aspects by respondents. These factors could be labelled in the following way: first, an 'instrumental and trade-off' factor (good pay and good job security; generous holidays, good working hours and not too much pressure; pleasant people to work with and good working conditions); second, a 'social' factor (an interesting job, a useful job, a responsible job, a respected job and meeting interesting people); and third, a 'self-fulfilment' factor (chances for promotion, possibility of achievement, opportunities to use initiative, opportunity to use one's abilities). The factor items do not have the same meaning in all circumstances. In accordance with a number of other conclusions [Halman 1996], the impact of age, social class and education proved decisive for work-value preferences in the Czech Republic in 1999. Lower-class members are more likely than the others to emphasise the instrumental side of work; lower-middle and middle-class members emphasise the social component and upper and upper-middle-class members the self-fulfilling function of work. ${ }^{18}$ In the European context, these results correspond with greater emphasis on the instrumental dimension of work (with particularly strong importance attributed to 'good pay' and 'good job

\footnotetext{
17) According to Yankelowich [1985], this trend is reflected in the shift from instrumental towards expressive orientation in work values.

${ }^{18}$ ) It is a pity that data on leisure-time activities and on certain taste preferences is not available at the same time, as this would make it possible to constitute a class space by combining all these aspects in a way similar to that used by Pierre Bourdieu [1994, 1999]. 
security') in poorer post-communist countries, as opposed to the greater emphasis on the self-fulfilment dimension of work in richer EU countries. In comparison with other European countries, the Czech population is less concerned with the social dimension of work ('a useful job', 'a responsible job'), and also with certain components of the selffulfilment dimension of work ('chances for promotion', 'possibility of achievement' and 'opportunity to use initiative').

Even today, however, work is generally highly valued in Czech society ( $94 \%$ of respondents find it important and 53\% even very important), as well as in the whole of Europe, not only for its instrumental character (source of income), but also as a social imperative (particularly in the middle class). Out of the surveyed dimensions of everyday life, only the family scored higher (it is very important for $85 \%$ of respondents). Both women and men, and members of individual social classes place great importance on work as a part of their life. A similar agreement was identified in opinions on leisure time (on average, leisure is important for $79 \%$ of respondents and very important for $21 \%$ ), as the opposite of paid work. At the same time, the Czechs are relatively highly satisfied with their specific jobs. It is thus possible to say that the data do not indicate a decline in the importance of work. ${ }^{19}$

PETR MAREŠ is an associate professor and head of the Department of Sociology at the School of Social Studies at Masaryk University in Brno (Czech Republic). He is interested in social problems, inequalities, unemployment, poverty and the methodology of social sciences. He publishes mainly in the Czech Sociological Review. He is the author of a number of books: Unemployment as a Social Problem (Prague: SLON 1994, 1998); The Status of the Poor (Occasional Papers in European Studies 7, Centre for European Studies, Colchester, University of Essex); Sociology of Inequality and Poverty (Prague: SLON 1999).

\section{References}

Adriaamsens, Hans 1994. "Citizenship, Work and Welfare." Pp. 66-75, in The Condition of Citizenship, ed. by Bart van Steenbergen. London: Sage.

Beck, Ulrich 1992. Risk Society. Towards a New Modernity. London: Sage.

Beck, Ulrich 1998. Democracy without Enemies. Cambridge: Polity Press.

Beck, Ulrich 2000. The Brave New World of Work. Cambridge: Polity Press.

Bell, Daniel 1974. The Coming of Post-Industrial Society. London: Heinemann.

Bělohradský, Václav 1999. “Antinomie globalizace, vzdělanostní společnost 2000 [The Antinomy of Globalisation and the Knowledge Society]". Pp. 33-79 in Eseje o nedávné minulosti a blizké budoucnosti [Essays on the Recent Past and the Near Future], by Václav Bělohradský et al. Praha: G plus G.

Bourdieu, Pierre 1994. Raisons practiques. Sur la théorie de l'action. Paris: Editions du Seuil.

Bourdieu, Pierre 1999. Teorie jednání. Praha: Karolinum.

Braverman, Harry 1974. Labor and Monopoly Capital. The Degradation of Work in the Twentieth Century. New York: Monthly Review Press.

19) After all, a number of authors have described the progressive importance of work (in terms of paid work). Wilson [1997], for instance, uses the example of the formation of an underclass in the United States to illustrate the role of job scarcity in this process and the associated changes in attitudes to work. 
Dahrendorf, Ralf 1990. Modern Social Conflict. An Essay on Politics of Liberty. Berkeley: University of California Press.

Dean, Mitchell 1991. The Constitution of Poverty. Toward a Genealogy of Liberal Governance. London: Routledge.

European Values Study 1991. (Data Set)

European Values Study 1999. (Data Set)

Fourastié, Jean 1965. Les 40000 heures. Paris: Robert Laffont.

Friedmann, Georges 1970. Le travail en miette. Paris: Gallimard.

Gesano, Guiseppe 1999. "Who is Working in Europe?" Pp. 77-139 in Unity in Diversity, European Population Conference. The Hague: Kluwer Academic Publisher.

Giddens, Anthony 1989. Sociology. Cambridge: Polity Press.

Giddens, Anthony 1994. Beyond Left and Right. The Future of Radical Politics. Cambridge: Polity Press.

Gorz, André 1999. Reclaiming Work. Beyond the Wage-Based Society. Cambridge: Polity Press.

Halman, Loek 1996. Individualization and Fragmentation of Work Values. Evidence from the European Values Studies. Tilburg: WORC - Work and Organization Research Centre.

Jahoda, Marie 1979a. "The Impact of Unemployment in the 1930s and 1970s." Bulletin of the British Psychological Society 32: 309-314.

Jahoda, Marie 1979b. “The Psychological Impact of Unemployment.” New Society 43: 118-120.

Keynes, John, M. 1931. "Economic Possibilities for our Grandchildren.” Pp. 364-372 in Essays in Persuasion, by John Maynard Keynes. London: Macmillan.

Marcuse, Herbert 1964. One-Dimensional Man. Studies in the Ideology of Advanced Industrial Society. Boston: Beacon Press.

Marx, Karel 1978. Ekonomicko filozofické rukopisy (Ökonomisch-philosophische Manuskripte aus dem Jahre 1844). Praha: Svoboda.

McQuitty, L. L. 1964. "Capabilities and Improvements of Linkage Analysis as a Clustering Method.” Educational and Psychological Measurement 24: 441-456.

Možný, Ivo 1974. "Význam sféry práce pro vytváření socialistického způsobu života [Significance of Work for the Establishment of the Socialist Way of Life].” Pp. 41-52 in Studia minora facultatis Philosophicae Universitatis brunensis, G18. Brno: Universita J. E. Purkyně.

Ouchi, W. G. 1981. Theory Z - How American Business Can Meet the Japanese Challenge. Reading: Addison Wesley.

Peters, Tom 1987. Thriving on Chaos. Handbook for a Management Revolution. New York: Alfred A. Knopf.

Pongs, Armin 1999. In welcher Gesselschaft leben wir eigentlich? München: Dilemma Verlag.

Toffler, Alvin 1985. The Adaptive Corporation. London, Pan Books.

Yankelowich, D. et al. 1985. The World at Work. New York: Octogon.

Wilson, William J. 1997. When Work Disappears. The World of the New Urban Poor. New York: Alfred A. Knopf. 